\title{
Depth variation in terrestrial particulate organic matter exploitation by marine coastal benthic communities off the Rhone River delta (NW Mediterranean)
}

\author{
Audrey M. Darnaude ${ }^{1,2, *}$, Chantal Salen-Picard ${ }^{1}{ }^{1}$ Mireille L. Harmelin-Vivien ${ }^{1}$ \\ ${ }^{1}$ Centre d'Océanologie de Marseille, CNRS UMR 6540, Université de la Méditerranée, Station Marine d'Endoume, \\ 13007 Marseille, France
}

${ }^{2}$ Present address: The Centre for Environment, Fisheries and Aquaculture Science, Lowestoft Laboratory, Pakefield Road, Lowestoft, Suffolk NR33 0HT, UK

\begin{abstract}
Carbon and nitrogen stable isotopes were used to study depth variation in terrestrial particulate organic matter (POM) sedimentation off the mouth of the Rhone River delta, and its use by the main benthic invertebrates (polychaetes, crustaceans, molluscs and echinoderms) and flatfishes (Arnoglossus laterna, Buglossidium luteum and Solea solea). Coastal water POM and surface sediment exhibited low $\delta^{13} \mathrm{C}$ values, denoting dominance of terrestrial material in their carbon pools ( 25 to $80 \%$ and $>50 \%$, respectively), but the importance of river input differed as a function of depth. Terrestrial organic matter contribution to the total POM was greatest at 30-50 m (72 to 99\%), and least at $70-100 \mathrm{~m}$ depth (25 to $77 \%)$. Most of the invertebrate groups studied $\left(\delta^{13} \mathrm{C}=-24.5\right.$ to $-17.5 \%$; $\delta^{15} \mathrm{~N}=4.3$ to $9.7 \%$ o) mainly relied on marine primary production irrespective of depth. However, deposit-feeding polychaetes mainly exploited terrestrial POM, and carnivorous and suspension-feeding polychaetes, bivalves, brachyurans and shrimps (Caridea) showed a partial uptake of terrestrial POM, depending on its availability. Incorporation of terrestrial POM by flatfishes $\left(\delta^{13} \mathrm{C}=-22.4\right.$ to $-16.8 \%$; $\delta^{15} \mathrm{~N}=9.7$ to $11.2 \%$ ) was species- and depth-dependent. It was related not only to the fishes' diets but also to the trophic adaptability of their prey. $S$. solea, the main consumer of deposit-feeding polychaetes, showed the lowest $\delta^{13} \mathrm{C}$ irrespective of depth, but flatfish exploitation of terrestrial POM peaked at 30-50 m, where both polychaete consumption by fishes and terrestrial POM use by the benthos were maximal. Unlike most estuarine systems, terrestrial inputs in deltaic areas can therefore peak at intermediate depths, where some of the marine macrobenthos, including flatfishes, efficiently exploit them. These results allow better assessment of the role of river input to marine coastal zones in increasing fish abundance, and will therefore be of major interest for demersal fisheries management off deltaic areas.
\end{abstract}

KEY WORDS: River inputs $\cdot$ Coastal ecosystems $\cdot$ Macrobenthos $\cdot$ Flatfishes $\cdot$ Stable isotopes

\section{INTRODUCTION}

The enhancement of the productivity of coastal benthic ecosystems by land-based run-off has been demonstrated in various areas (e.g. Cloern 2001, Maslowski 2003), but has been linked mainly to river input of nutrients and subsequent increases in plank- ton production and deposition in the benthos (Ardisson \& Bourget 1997, Josefson \& Conley 1997). The role played by terrestrial particulate organic matter (POM) input to the benthos has not been extensively studied (Salen-Picard \& Arlhac 2002, Darnaude et al. 2004), especially in terms of spatial variability. Terrestrial POM exploitation by benthic invertebrates has been 
detected in several estuarine environments, where it decreases with increasing depth and salinity (Peterson et al. 1985, Riera et al. 1999, Chanton \& Lewis 2003). However, the situation can differ in deltaic coastal zones where POM sedimentation is directly influenced by marine currents, especially in weakly tidal seas like the Mediterranean. In such areas, near-bottom salinity remains quite constant due to weak vertical water mixing, even in shallow waters. Coastal benthic community composition is therefore more stable than in estuarine environments, where salinity tolerance controls species abundance. This could lead to specific patterns of terrestrial POM exploitation by the benthic macrobenthos, which may differentially impact the population dynamics of coastal demersal fishes.

To assess the spatial variability of terrestrial POM sedimentation and its use under such conditions, a stable isotope study of marine benthic food webs was conducted off the mouth of the Rhone River (NW Mediterranean). Stable isotopes have successfully been used to trace the transfer of organic matter of different origins through estuarine and coastal food webs (Haines \& Montague 1979, Riera \& Richard 1996, Bouillon et al. 2000, Kaehler et al. 2000, Pinnegar \& Polunin 2000). Provided that primary producers have distinct isotopic signatures, as has previously been shown for terrestrial and marine producers (Ostrom \& Fry 1993), they constitute a powerful tool for discriminating between organic matter sources (Dufour \& Gerdeaux 2001, Vander Zanden \& Rasmussen 2001). They also provide a good description of food web structure and trophic transfer within animal communities (Kwak \& Zedler 1997, Riera et al. 1999, Kaehler et al. 2000, Polunin et al. 2001, Renones et al. 2002, Takai et al. 2002). Carbon isotope composition in animals usually provides clues about the initial origin of their food through the low increases in $\delta^{13} \mathrm{C}$ generally observed between prey and predators $(<2 \%$, mean 1\%o) (De Niro \& Epstein 1978, Wada et al. 1991). Nitrogen isotope signatures can be used to define the trophic levels of organisms, as $\delta^{15} \mathrm{~N}$ generally increases by 2.5 to $4.5 \%$ o from food to consumer (Minagawa \& Wada 1984, Post 2002).

In the present study, mean annual $\delta^{13} \mathrm{C}$ and $\delta^{15} \mathrm{~N}$ were assessed at different depth ranges for the main benthic organic matter reservoirs (water and sediment), the main macrobenthic invertebrates and the 3 most abundant flatfish species off the Rhone River: Arnoglossus laterna (Walbaum, 1792), Buglossidium luteum (Risso, 1810) and Solea solea (Linnaeus, 1758). The isotopic signatures obtained were then compared to those of the 2 main POM sources to this area (Rhone River POM and marine phytoplankton) to determine (1) if there were bathymetric differences in POM sedimentation and availability to the benthos seawards of the Rhone River, (2) if the intensity of terrestrial POM use by the benthos varied according to availability, and (3) if differences in terrestrial POM use by the benthos, if any, could have consequences for fishes at higher trophic levels.

\section{MATERIALS AND METHODS}

Study area. The study area $\left(43^{\circ} 14^{\prime}\right.$ to $43^{\circ} 22^{\prime} \mathrm{N}$, $4^{\circ} 54^{\prime}$ to $5^{\circ} 03^{\prime} \mathrm{E}$, Fig. 1) is located in the Gulf of Lions (NW Mediterranean Sea), off the mouth of the main branch of the Rhone River, which is the main run-off to the Mediterranean (mean yearly discharge of $1700 \mathrm{~m}^{3}$ $\mathrm{s}^{-1}$ ). The river is responsible for $50 \%$ of the annual primary production of the Gulf of Lions (Lochet \& Leveau 1990), irrespective of year. Its solid discharge varies however from 1.4 to $22.7 \times 10^{6} \mathrm{t} \mathrm{yr}^{-1}$ (Sempéré et al. 2000 ), with $6.2 \times 10^{6} \mathrm{t} \mathrm{yr}^{-1}$ of terrestrial particulate matter on average discharged onto the continental shelf (Pont 1997). Most material accumulates within the Rhone pro-delta, which extends from the shoreline to 90-100 m depth (Touzani \& Giresse 2002). As macroand microphytobenthic production is low in this area (Bodoy \& Plante-Cuny 1980), surface seawater POM (phytoplankton) is the main supply of marine-sourced organic matter within the benthic ecosystems studied (Cauwet et al. 1990). The main organic matter reservoirs accessible to coastal benthic invertebrates are therefore plume water POM (from a mixture of river and seawater POM) and surface sediment organic matter (derived mainly from the deposition of plume and seawater POM). Fragments of terrestrial plants can also arrive by river discharge, but their exploitation is negligible (Darnaude et al. 2004).

Sampling. Adult flatfishes, macrobenthic invertebrates, plume water, surface sediment and Rhone River and offshore seawater POM were collected seasonally (winter, spring, summer) between March 2000 and November 2001. The mean annual values obtained therefore reflected the seasonal variability of their isotopic signatures, as sampling encompassed the main periods of high (winter, spring) and low (summer) flow of the river (Sempéré et al. 2000). Rhone River POM was collected $6 \mathrm{~km}$ upstream of the river mouth and seawater POM was sampled in the Gulf of Marseilles, outside the Rhone River influence (Frioul island: $43^{\circ} 15^{\prime} \mathrm{N}, 5^{\circ} 18^{\prime} \mathrm{E}$; salinity $>37.8$ ). River plume water, surface sediment, macrobenthos and flatfishes were collected seawards of the Rhone River mouth, at 0-20, 30-50 and 70-100 $\mathrm{m}$ depths. These 3 depth ranges, the characteristics of which are shown in Fig. 1, were representative of the main sediment types and benthic species assemblages found within the river pro-delta. 
Rhone River, plume and offshore seawater POM samples (3 site $^{-1}$ season $^{-1}$ ) were obtained by filtering the corresponding water samples $\left(3 \times 201\right.$ site $^{-1}$ season $^{-1}$, pre-filtered on $250 \mu \mathrm{m}$-mesh sieves to remove zooplankton and detritus) on previously combusted and weighed Whatman GF/F glass-fibre filters. Sediment samples $\left(3\right.$ site $^{-1}$ season $\left.^{-1}\right)$ were collected with a multicore sampler. Only the upper $2 \mathrm{~cm}$ of the cores were kept for isotope analysis after the removal of macroscopic organisms. Macrobenthic invertebrates were collected with a pneumatic suction-sampler at 0-5 m depth, and with a Smith-McIntyre grab at greater depths (10-20, 30-50 and 70-100 m). They were sorted by taxon, and polychaetes were determined to species level for sorting to trophic group (Fauchald \& Jumars 1979). All were maintained live in filtered water from the sampling site for $24 \mathrm{~h}$ to allow gut evacuation. They were then killed and stored separately, after dissection of large individuals to remove hard parts and digestive tracts. Flatfishes were captured by day and night trawl- ing at 10, 30 and $90 \mathrm{~m}$ depth. Their total lengths (TL in $\mathrm{cm})$ were recorded, and their guts removed and preserved in $10 \%$ neutralised formaldehyde solution for stomach content analysis. Dorsal white muscle samples were taken for isotope analysis, since this tissue exhibits the lowest variation in $\delta^{13} \mathrm{C}$ and $\delta^{15} \mathrm{~N}$ (Pinnegar \& Polunin 1999). All samples were kept frozen before being processed for isotope analysis.

Flatfish diets. To assess the exact composition of flatfish diet for each depth, the stomach contents of 596 Arnoglossus laterna ( $\mathrm{TL}=81$ to $132 \mathrm{~mm}$ ), 92 Buglossidium luteum (TL $=83$ to $126 \mathrm{~mm}$ ) and 97 Solea solea ( $\mathrm{TL}=284$ to $374 \mathrm{~mm}$ ) were analysed. For each sampling depth (0-20, 30-50 and 70-100 m) and species, prey items were identified, sorted and counted under a binocular microscope, following the procedure described in Darnaude et al. (2001). They were identified to class, except for polychaetes, which were determined to species. After $24 \mathrm{~h}$ drying at $45^{\circ} \mathrm{C}$, prey category dry weights were recorded. The corresponding

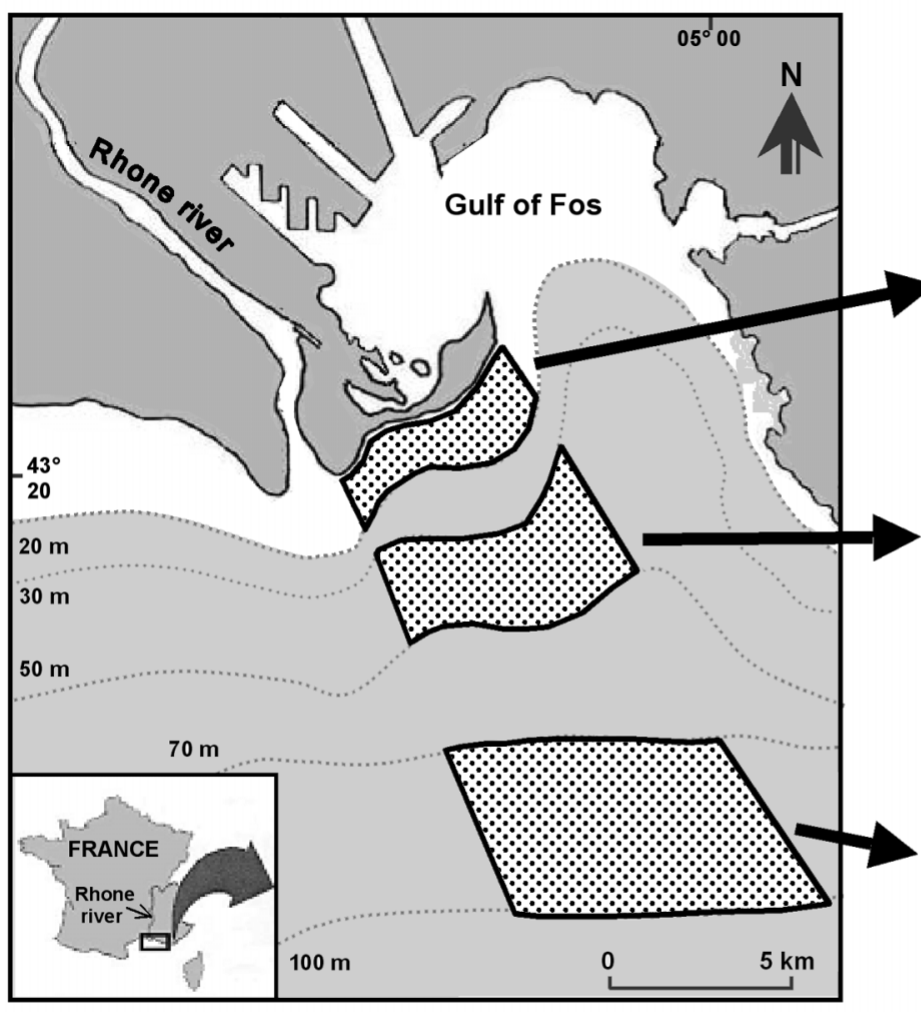

Sediment charateristics:

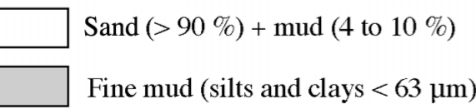

\section{Composition (density \%) of benthic communities}
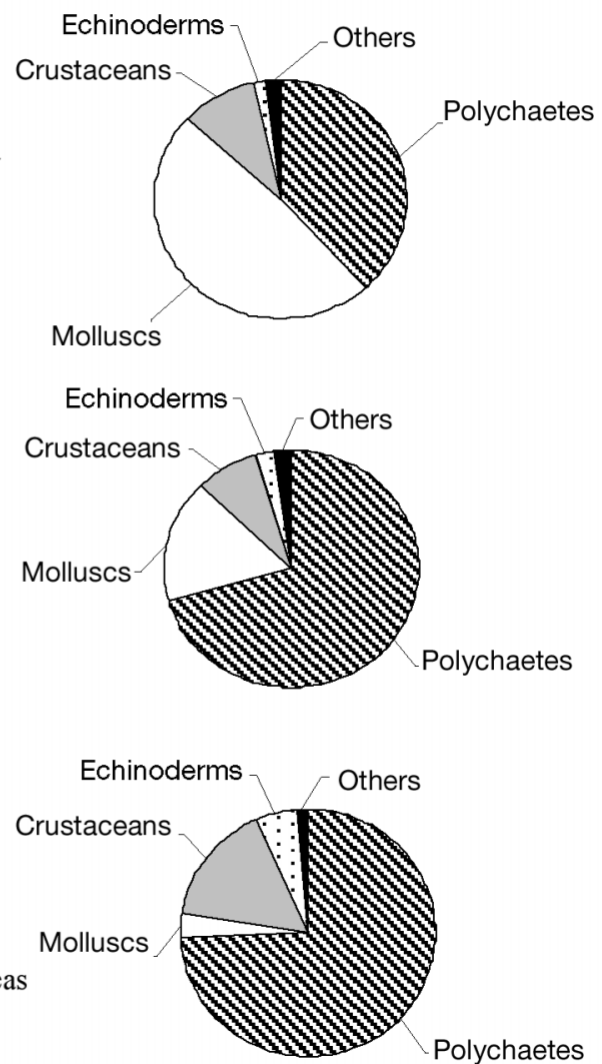

Fig. 1. Location and main biotic and abiotic characteristics of 3 depth ranges $(0-20,30-50$ and $70-100 \mathrm{~m})$ sampled off the mouth of the Rhone River, NW Mediterranean 
prey percentages in diet (W\%), calculated for each fish species and depth, allowed us to determine if interspecific and bathymetric changes in fish isotopic signatures were due to modifications in fish diet and/or in prey signatures.

Stable isotope analyses. Water POM samples (on $\mathrm{GF} / \mathrm{F}$ filters) were freeze-dried and cut into small pieces. Animal and sediment samples were freezedried and ground into a fine powder $(<60 \mu \mathrm{m})$. Samples from fishes (white muscle) and large invertebrates (polychaete and mollusc soft tissues) were analysed without any prior treatment. Samples of water POM, sediment and small invertebrates (e.g. bivalve juveniles, crustaceans, ophiurids) were divided into 2 subsamples: 1 subsample, for carbon isotope analysis, was acidified with $1 \% \mathrm{HCl}$ solution to remove carbonates, rinsed with distilled water and oven-dried at $40^{\circ} \mathrm{C}$ for $24 \mathrm{~h}$, as carbonates present higher $\delta^{13} \mathrm{C}$ values than organic carbon (De Niro \& Epstein 1978). The other subsample, for nitrogen isotope analysis, was not acidified since acidification results in enrichment of $\delta^{15} \mathrm{~N}$ (Pinnegar \& Polunin 1999).

${ }^{13} \mathrm{C} /{ }^{12} \mathrm{C}$ and ${ }^{15} \mathrm{~N} /{ }^{14} \mathrm{~N}$ ratios in the samples were determined by continuous flow isotope mass spectroscopy (CF-IRMS) (Preston \& Owens 1983). Weighed samples of material (1 mg for fishes and prey, $10 \mathrm{mg}$ for filters and sediment) were oxidised and the $\mathrm{CO}_{2}$ and $\mathrm{N}_{2}$ passed to a single-inlet dual-collector mass spectrometer (PDZ Europa ANCA SL 20-20 system). Isotope ratios were expressed as parts per thousand (\%) differences from a standard reference material:

$$
\delta X=\left[\left(R_{\text {sample }} / R_{\text {standard }}\right)-1\right] \times 10^{3}
$$

where $X$ is ${ }^{13} \mathrm{C}$ or ${ }^{15} \mathrm{~N}, R$ is the corresponding ratio ${ }^{13} \mathrm{C} /{ }^{12} \mathrm{C}$ or ${ }^{15} \mathrm{~N} /{ }^{14} \mathrm{~N}$ and $\delta$ is the measure of heavy to light isotope in the sample.

The international standard references are Vienna Pee Dee Belemnite (VPDB) for carbon, and atmospheric $\mathrm{N}_{2}$ for nitrogen. However, to calibrate the system and prevent measurement drift with time, corn flour and cod (Gadus morhua L.) white muscle tissue, with known signatures, were used as internal references when analysing water and sediment samples and animal materials, respectively. Experimental precision $\left(0.11 \%\right.$ or $\delta^{13} \mathrm{C}$ and $0.14 \%$ for $\left.\delta^{15} \mathrm{~N}\right)$ was calculated based on the standard deviation of the internal reference replicates.

Data analysis. $\delta^{13} \mathrm{C}$ and $\delta^{15} \mathrm{~N}$ differences between main organic matter sources (Rhone and seawater POM) and reservoirs (plume water POM and surface sediment) were analysed separately using 1-way (category) analyses of variance (ANOVA). We subsequently performed 2-way (depth range $\times$ category) ANOVAs on plume water POM and sediment $\delta^{13} \mathrm{C}$ and $\delta^{15} \mathrm{~N}$ to detect any differences in isotopic signature between depths and reservoirs. Between invertebrates and fishes, differences in isotopic signature were tested using a 2-way (depth range $\times$ category) multivariate analysis of variance (MANOVA) completed by 2-way (depth range $\times$ category) ANOVAs performed separately on $\delta^{13} \mathrm{C}$ and $\delta^{15} \mathrm{~N}$ values. In each case, data were log-transformed to stabilise variances. Post-hoc comparisons of means were performed using StudentNewman-Keuls tests, and only isotopic signature differences with associated p-values under 0.05 were considered to be statistically significant.

Estimations of terrestrial POM percentages $(F \%)$ in the plume water 'reservoir' were obtained at each depth range using the equation:

$$
F \%=\left[\left(\delta^{13} \mathrm{C}_{(X)}-M\right) /(R-M)\right] \times 100
$$

where $\delta^{13} C_{(X)}$ is the signature of the plume water POM, and $M$ and $R$ are the carbon signatures of the marine and Rhone River POMs, respectively.

Superficial sediment organic matter corresponds to an undifferentiated mix of detritus (e.g. faecal pellets, deposited dead phyto- or zooplankton, terrestrial detritus, benthos pseudo-faeces and faeces) and micro- or meiofaunal organisms that could not be removed prior to analysis. All these were assumed to have isotopic signatures varying from those of marine and terrestrial POM to those of organisms feeding directly on them. Considering that trophic enrichment in $\delta^{13} \mathrm{C}$ generally averages $1 \%$ (De Niro \& Epstein 1978), ranges of the potential contribution of terrestrial POM to sediment organic matter were therefore obtained by alternatively replacing $M$ by $M+1 \%$, and $R$ by $R+1 \%$ in Eq. (2).

\section{RESULTS}

\section{Origin of organic matter}

The main organic matter sources and reservoirs showed significant differences in $\delta^{15} \mathrm{~N}(\mathrm{p}<0.001)$ and $\delta^{13} \mathrm{C}(\mathrm{p}<0.001)$. The mean nitrogen signature was significantly lower in seawater POM $(<2.5 \%)$ and higher in pro-delta surface sediment $(>3.5 \%$ ) than in Rhone River and plume water POM (Table 1). The difference was statistically significant between reservoirs ( $p<$ 0.01 ) but not between depths: $\delta^{15} \mathrm{~N}$ values always approached $3 \%$ for the plume water POM and $4 \%$ for the sediment. Mean carbon signature $\left(\delta^{13} \mathrm{C}\right)$ varied from $-26.11 \%$ in Rhone River POM to $-22.36 \%$ in seawater POM. Plume water POM and surface sediment showed intermediate $\delta^{13} \mathrm{C}$ values (Table 1). The carbon signature varied with reservoir $(p<0.05)$ and depth ( $\mathrm{p}<0.01)$. Plume water POM and surface sediment $\delta^{13} \mathrm{C}$ were similar at $30-50 \mathrm{~m}$ depth, but significantly different $\left(\Delta \delta^{13} \mathrm{C}>0.5 \%\right)$ at $0-20$ and $70-100 \mathrm{~m}$. Plume 
Table 1. Carbon and nitrogen stable isotope signatures (mean $\% \pm \mathrm{SE}$ ) of main sources and reservoirs of particulate organic matter (POM) in the benthic coastal ecosystems off the mouth of the Rhone River. $\mathrm{n}=$ sample size. $0-20 \mathrm{~m}$ : coastal fine sands, 30-50 m: upper mud belt, 70-100 m: deeper mud belt

\begin{tabular}{|lccc|}
\hline $\begin{array}{l}\text { Source/reservoir } \\
\text { Main POM sources }\end{array}$ & $\mathrm{n}$ & $\delta^{13} \mathrm{C}$ & $\delta^{15} \mathrm{~N}$ \\
\hline $\begin{array}{l}\text { Rhone River POM } \\
\text { (terrestrial) }\end{array}$ & 9 & $-26.11 \pm 0.23$ & $3.47 \pm 0.42$ \\
$\begin{array}{l}\text { Offshore seawater POM } \\
\text { (marine) }\end{array}$ & 9 & $-22.36 \pm 0.24$ & $2.33 \pm 0.11$ \\
Main POM reservoirs & & & \\
$\quad$ Plume POM & & & \\
$\quad 0-20 \mathrm{~m}$ & 9 & $-24.27 \pm 0.31$ & $3.05 \pm 0.21$ \\
$\quad 30-50 \mathrm{~m}$ & 9 & $-25.37 \pm 0.16$ & $3.10 \pm 0.23$ \\
$\quad 70-100 \mathrm{~m}$ & 9 & $-23.31 \pm 0.25$ & $2.96 \pm 0.41$ \\
$\quad \begin{array}{l}\text { Surface sediment } \\
\quad 0-20 \mathrm{~m}\end{array}$ & 9 & $-24.86 \pm 0.21$ & $3.79 \pm 0.18$ \\
$\quad 30-50 \mathrm{~m}$ & 9 & $-25.06 \pm 0.14$ & $4.09 \pm 0.17$ \\
$\quad 70-100 \mathrm{~m}$ & 9 & $-24.25 \pm 0.14$ & $3.56 \pm 0.16$ \\
& & & \\
\hline
\end{tabular}

water POM $\delta^{13} \mathrm{C}$ varied significantly between depths, with a maximum value at $70-100 \mathrm{~m}$ and a minimum value at $30-50 \mathrm{~m}$. Surface sediment $\delta^{13} \mathrm{C}$ was more stable, with a significantly higher value only at $70-100 \mathrm{~m}$. Plume water POM and surface sediment $\delta^{13} \mathrm{C}$ values differed more from seawater POM $(-1.9 \%$ to $-3.0 \%)$ than from river POM $(+0.7$ to $+1.9 \%)$, except at $70-100 \mathrm{~m}$. This result indicated a substantial contribution of terrestrial material to the organic matter pools of plume water (25 to $80 \%)$ and surface sediment (>50\%), especially at 30-50 m (Table 2 ).

\section{Macrobenthic communities and benthic food webs}

Stable isotope signature varied between organism categories $(\mathrm{p}<0.001)$ and sampling depths $(\mathrm{p}<0.001)$ (Table 3). This suggested species-specific and depthdependent differences in food sources and trophic levels for both invertebrates and fishes. At 0-20 m depth, invertebrate carbon signatures were highly variable (Table 3) and polychaetes had significantly lower mean $\delta^{13} \mathrm{C}$ than other invertebrate groups. This was attributable mainly to surface and subsurface depositfeeding polychaetes, whose isotopic signatures indicated a diet composed mainly of Rhone River POM (trophic enrichment of 1 to $1.5 \%$ in $\delta^{13} \mathrm{C}$ and 2.4 to $3.4 \%$ in $\delta^{15} \mathrm{~N}$ ) (Fig. 2). The carbon and nitrogen signatures of carnivorous polychaetes suggested that they too were dependent on river POM, but at a higher trophic level, via the ingestion of organisms consuming surface sediment (i.e. mainly terrestrial POM). With the exception of bivalves, whose isotopic signatures
Table 2. Respective contribution (\%) of terrestrial and marine particulate organic matter (POM) to plume water and surface sediment organic matter pools in the benthic coastal ecosystems off the mouth of the Rhone River. 0-20 m: coastal fine sands; 30-50 m: upper mud belt; 70-100 m: deeper mud belt

\begin{tabular}{|lcc|}
\hline Source & $\begin{array}{c}\text { \% terrestrial POM } \\
\text { (Rhone River POM) }\end{array}$ & $\begin{array}{c}\text { \% marine POM } \\
\text { (offshore seawater POM) }\end{array}$ \\
\hline \multicolumn{2}{|c|}{ Plume water POM } & \\
$0-20 \mathrm{~m}$ & 50.9 & 49.1 \\
$30-50 \mathrm{~m}$ & 80.3 & 19.7 \\
$70-100 \mathrm{~m}$ & 25.3 & 74.7 \\
Surface sediment & \\
$0-20 \mathrm{~m}$ & $66.7-93.3$ & $6.7-33.3$ \\
$30-50 \mathrm{~m}$ & $72.0-98.7$ & $1.3-28.0$ \\
$70-100 \mathrm{~m}$ & $50.4-77.1$ & $22.9-49.6$ \\
\multicolumn{2}{l}{} \\
\hline
\end{tabular}

suggested sizeable uptake of organic matter of terrestrial origin, the $\delta^{13} \mathrm{C}$ and $\delta^{15} \mathrm{~N}$ of other invertebrates indicated a diet based exclusively on organic matter of marine origin (Fig. 2). Amongst these, however, shrimps (Caridae) and pagurids had isotopic signatures suggesting a partial reliance on organic matter source(s) with higher $\delta^{13} \mathrm{C} \quad(>-19 \%)$. Therefore, although being the 2 principal POM sources to the area, Rhone River POM and marine phytoplankton were not the exclusive POM sources to benthic invertebrates at $0-20 \mathrm{~m}$. In this depth range, the flatfishes were at the top of the marine phytoplankton-based food web (Fig. 2). They had similar $\delta^{15} \mathrm{~N}$, indicating proximal trophic levels (Table 3), but different diets (Table 4) and carbon signatures (Table 3). Buglossidium luteum and Solea solea, which fed mainly on deposit-feeding or carnivorous polychaetes and bivalves, had significantly lower $\delta^{13} \mathrm{C}$ than Arnoglossus laterna, which essentially preyed on amphipods, suspension-feeding polychaetes and carideans.

At $30-50 \mathrm{~m}$ depth, polychaetes had a significantly lower $\delta^{13} \mathrm{C}$ than other invertebrates (Table 3). All of them relied mainly on organic matter of terrestrial origin for growth (Fig. 3). The observed isotopic signatures of suspension-feeding and deposit-feeding polychaetes suggested a diet composed of a mixture of Rhone River POM and surface sediment (trophic enrichment by 1 to $2 \% \delta^{13} \mathrm{C}$ and 3.2 to $4.0 \%{ }^{15} \mathrm{~N}$ ). Carnivorous polychaete isotopic signatures suggested a diet of organisms feeding on sediment organic matter. The $\delta^{13} \mathrm{C}$ and $\delta^{15} \mathrm{~N}$ of other benthic invertebrates suggested diets based mainly on marine organic matter. Bivalve and brachyurid signatures did however suggest a partial uptake of terrestrial POM. The flatfishes showed similar $\delta^{15} \mathrm{~N}$ but statistically different carbon signatures and diets. Solea solea, which preyed mainly on polychaetes (Table 4), was at the top of the terrestrial-POM-based food web, whereas Arnoglossus lat- 
Table 3. $\delta^{13} \mathrm{C}$ and $\delta^{15} \mathrm{~N}$ values (mean $\% \pm \mathrm{SE}$ ) of most abundant invertebrates (polychaetes, crustaceans, molluscs, echinoderms) and flatfishes sampled off the mouth of the Rhone River. Number of samples analysed per category and depth $=3$ for invertebrates and 10 for fishes. -: benthic organism rare or absent within that depth range

\begin{tabular}{|c|c|c|c|c|c|c|}
\hline \multirow{2}{*}{ Taxon } & \multicolumn{2}{|c|}{$-0-20 \mathrm{~m}-$} & \multicolumn{2}{|c|}{$-30-50 \mathrm{~m}$} & \multicolumn{2}{|c|}{$-70-100 \mathrm{~m}$} \\
\hline & $\delta^{13} \mathrm{C}$ & $\delta^{15} \mathrm{~N}$ & $\delta^{13} \mathrm{C}$ & $\delta^{15} \mathrm{~N}$ & $\delta^{13} \mathrm{C}$ & $\delta^{15} \mathrm{~N}$ \\
\hline Polychaetes & $-22.65 \pm 0.17$ & $7.12 \pm 0.11$ & $-23.36 \pm 0.17$ & $7.17 \pm 0.13$ & $-21.54 \pm 0.07$ & $7.17 \pm 0.03$ \\
\hline Surface deposit feeders & $-24.94 \pm 0.01$ & $5.84 \pm 0.01$ & $-24.36 \pm 0.02$ & $6.09 \pm 0.01$ & $-21.82 \pm 0.02$ & $6.40 \pm 0.02$ \\
\hline Sub-surface deposit feeders & $-24.52 \pm 0.29$ & $6.85 \pm 0.10$ & $-23.26 \pm 0.04$ & $7.06 \pm 0.03$ & $-23.65 \pm 0.12$ & $7.01 \pm 0.01$ \\
\hline Suspension feeders & $-19.21 \pm 0.02$ & $7.24 \pm 0.02$ & $-23.76 \pm 0.09$ & $6.43 \pm 0.05$ & $-20.39 \pm 0.03$ & $6.10 \pm 0.05$ \\
\hline Carnivores & $-21.94 \pm 0.04$ & $8.55 \pm 0.04$ & $-22.05 \pm 0.02$ & $9.12 \pm 0.01$ & $-20.32 \pm 0.06$ & $9.17 \pm 0.01$ \\
\hline Crustaceans & $-20.21 \pm 0.44$ & $6.10 \pm 0.30$ & $-20.57 \pm 0.24$ & $6.63 \pm 0.42$ & $-20.70 \pm 0.24$ & $5.69 \pm 0.30$ \\
\hline Copepods & $-21.49 \pm 0.06$ & $4.79 \pm 0.03$ & $-21.51 \pm 0.01$ & $4.77 \pm 0.04$ & $-21.51 \pm 0.07$ & $4.94 \pm 0.03$ \\
\hline Mysids & $-19.73 \pm 0.35$ & $9.18 \pm 0.50$ & $-19.57 \pm 0.35$ & $9.15 \pm 0.50$ & $-19.23 \pm 0.25$ & $8.75 \pm 0.44$ \\
\hline Cumaceans & $-21.43 \pm 0.07$ & $4.30 \pm 0.15$ & $-21.39 \pm 0.17$ & $4.37 \pm 0.14$ & $-21.42 \pm 0.05$ & $5.30 \pm 0.11$ \\
\hline Amphipods & $-21.45 \pm 0.10$ & $5.51 \pm 0.10$ & $-20.59 \pm 0.58$ & $5.20 \pm 0.20$ & $-20.45 \pm 0.12$ & $4.77 \pm 0.13$ \\
\hline Shrimps (Caridea) & $-18.44 \pm 0.18$ & $6.45 \pm 0.90$ & $-20.76 \pm 0.06$ & $8.27 \pm 0.50$ & $-19.60 \pm 0.45$ & $6.85 \pm 0.55$ \\
\hline Anomurans (Pagurids) & $-17.47 \pm 0.05$ & $7.25 \pm 0.06$ & $-18.77 \pm 0.06$ & $7.45 \pm 0.04$ & - & - \\
\hline Brachyurans & $-21.45 \pm 0.09$ & $6.23 \pm 0.05$ & $-21.89 \pm 0.08$ & $6.99 \pm 0.08$ & $-21.51 \pm 0.15$ & $5.38 \pm 0.10$ \\
\hline Molluscs & $-20.53 \pm 0.11$ & $7.57 \pm 0.07$ & $-20.68 \pm 0.09$ & $7.30 \pm 0.07$ & $-20.87 \pm 0.04$ & $5.76 \pm 0.04$ \\
\hline Bivalves & $-22.21 \pm 0.07$ & $5.42 \pm 0.05$ & $-22.85 \pm 0.08$ & $5.29 \pm 0.02$ & $-20.87 \pm 0.04$ & $5.76 \pm 0.04$ \\
\hline Gastropods & $-18.85 \pm 0.21$ & $9.73 \pm 0.02$ & $-18.52 \pm 0.03$ & $9.32 \pm 0.03$ & - & - \\
\hline Echinoderms & $-19.02 \pm 0.15$ & $7.85 \pm 0.31$ & $-19.32 \pm 0.07$ & $6.59 \pm 0.27$ & $-19.04 \pm 0.06$ & $6.18 \pm 0.12$ \\
\hline Ophiurids & $-19.02 \pm 0.15$ & $7.85 \pm 0.31$ & - & - & - & - \\
\hline Holothurians & - & - & $-19.32 \pm 0.07$ & $6.59 \pm 0.27$ & $-19.04 \pm 0.06$ & $6.18 \pm 0.12$ \\
\hline Flatfishes & $-18.10 \pm 0.36$ & $10.89 \pm 0.35$ & $-20.35 \pm 0.26$ & $10.86 \pm 0.25$ & $-18.47 \pm 0.46$ & $10.59 \pm 0.21$ \\
\hline Arnoglossus laterna & $-16.75 \pm 0.25$ & $10.49 \pm 0.47$ & $-19.28 \pm 0.16$ & $11.24 \pm 0.13$ & $-18.25 \pm 0.25$ & $9.69 \pm 0.12$ \\
\hline Buglossidium luteum & $-18.47 \pm 0.31$ & $11.18 \pm 0.21$ & $-20.77 \pm 0.44$ & $11.03 \pm 0.21$ & $-17.99 \pm 0.52$ & $10.97 \pm 0.21$ \\
\hline Solea solea & $-19.07 \pm 0.23$ & $11.00 \pm 0.13$ & $-22.36 \pm 0.36$ & $11.24 \pm 0.13$ & $-20.06 \pm 0.67$ & $11.05 \pm 0.23$ \\
\hline
\end{tabular}

erna, which mainly fed on crustaceans, was at the top of the phytoplankton-based food web (Fig. 3). These species had significantly lower and significantly higher carbon signatures than Buglossidium luteum, respec- tively. This latter species mainly consumed polychaetes, but also sizeable amounts of crustaceans (Table 4), which explains its intermediate position on the $\delta^{13} \mathrm{C}$ versus $\delta^{15} \mathrm{~N}$ graph (Fig. 3).

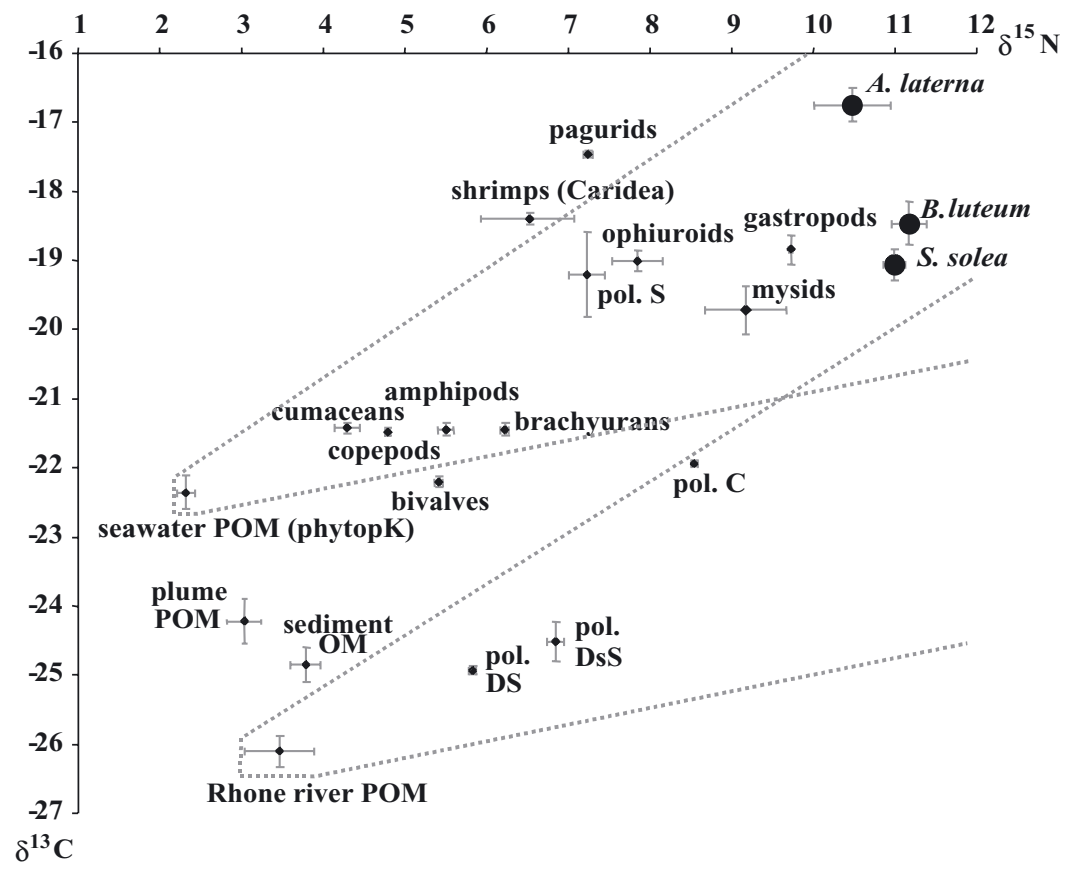

Fig. 2. Plot of $\delta^{13} \mathrm{C}$ versus $\delta^{15} \mathrm{~N}$ (mean $\% \pm \mathrm{SE}$ ) for main organic matter sources and reservoirs and macrobenthic taxa sampled off the mouth of the Rhone River at 0-20 m depth. •: flatfish positions (Arnoglossus laterna, Buglossidium luteum, Solea solea); phytopK: phytoplankton; POM: particulate organic matter; pol.: polychaetes; C: carnivore; DS: surface deposit feeder; DsS: subsurface deposit-feeder; S: suspension feeder. Dotted lines (corresponding to trophic increases of $+1 \%$ in $\delta^{13} \mathrm{C}$ and $+4.5 \%$ in $\delta^{15} \mathrm{~N}$, and of $+2 \%$ in $\delta^{13} \mathrm{C}$ and $+2.5 \%$ in $\delta^{15} \mathrm{~N}$ ) show upper and lower limits of the isotopic signature ranges expected for trophic transfer of exclusively marine or exclusively terrestrial organic matter (see 'Introduction' for details) 
Table 4. Diets (\% dry wt of prey in stomach contents) of Arnoglossus laterna (Al), Buglossidium luteum (Bl), Solea solea (Ss) over coastal fine sands $(0-20 \mathrm{~m})$ and upper $(30-50 \mathrm{~m})$ and deeper $(70-100 \mathrm{~m})$ mud belt off the mouth of the Rhone River. n: sample size $_{;}+$: values $<0.1 \%$; - : prey category not found

\begin{tabular}{|c|c|c|c|c|c|c|c|c|c|}
\hline \multirow[t]{2}{*}{ Prey } & \multicolumn{3}{|c|}{$-0-20 \mathrm{~m}-$} & \multicolumn{3}{|c|}{$-30-50 \mathrm{~m}$} & \multicolumn{3}{|c|}{$-70-100 \mathrm{~m}$} \\
\hline & $\begin{array}{c}A l \\
(\mathrm{n}=76)\end{array}$ & $\begin{array}{c}B l \\
(\mathrm{n}=30)\end{array}$ & $\begin{array}{c}\begin{array}{c}S s \\
(\mathrm{n}=32)\end{array}\end{array}$ & $\begin{array}{c}A l \\
(\mathrm{n}=312)\end{array}$ & $\begin{array}{c}B l \\
(\mathrm{n}=31)\end{array}$ & $\begin{array}{c}\text { Ss } \\
(\mathrm{n}=35)\end{array}$ & $\begin{array}{c}A l \\
(\mathrm{n}=208)\end{array}$ & $\begin{array}{c}B l \\
(\mathrm{n}=31)\end{array}$ & $\begin{array}{c}\text { Ss } \\
(\mathrm{n}=30)\end{array}$ \\
\hline Polychaetes & 30.8 & 46.0 & 37.8 & 28.8 & 69.9 & 88.3 & 6.2 & 18.1 & 73.5 \\
\hline Surface deposit-feeders & 8.3 & 15.2 & 15.5 & 4.1 & 10.2 & 8.8 & 1.7 & 5.1 & 36.7 \\
\hline Subsurface deposit-feeders & 0.6 & - & 13.6 & - & 36.3 & 71.5 & 1 & - & 29.1 \\
\hline Suspension-feeders & 16.3 & 4.6 & 2.7 & 17.9 & 0.8 & 0.9 & 1.0 & - & 1.5 \\
\hline Carnivores & 5.6 & 26.2 & 6.0 & 6.8 & 22.6 & 7.1 & 3.5 & 13.0 & 6.2 \\
\hline Crustaceans & 45.4 & 27.9 & 3.8 & 63.8 & 20.1 & 4.4 & 90.4 & 81.1 & 6.2 \\
\hline Copepods & - & 2.2 & - & + & - & - & 0.8 & 3.3 & - \\
\hline Mysids & 3.7 & 3.1 & - & 2.9 & 4.5 & 0.1 & 33.2 & 20.1 & - \\
\hline Cumaceans & 2.5 & 3.2 & 0.5 & 0.4 & 2.6 & 0.5 & 0.2 & 9.2 & - \\
\hline Amphipods & 18.0 & 11.8 & 0.5 & 2.9 & 8.1 & 0.1 & 3.4 & 23.5 & - \\
\hline Shrimps (Caridea) & 10.6 & 4.7 & 0.8 & 43.9 & 2.3 & 1.2 & 41.7 & 25.0 & 6.0 \\
\hline Anomurans (Paguridae) & - & - & 1.3 & 1.3 & - & 0.9 & - & - & + \\
\hline Brachyurans & 5.3 & 2.9 & 0.7 & 12.4 & 2.6 & 1.6 & 11.1 & - & 0.2 \\
\hline Molluscs & 4.4 & 17.2 & 37.5 & 1.2 & 9.2 & 1.2 & 0.1 & + & 5.8 \\
\hline Bivalves & 4.4 & 17.2 & 23.6 & 1.2 & 8.3 & 1.2 & 0.1 & + & 5.0 \\
\hline Gastropods & - & + & 13.9 & - & 0.9 & + & - & - & 0.8 \\
\hline Echinoderms & - & 0.9 & 20.0 & - & - & 5.4 & - & - & 9.2 \\
\hline Ophiurids & - & 0.9 & 20.0 & - & - & - & - & - & - \\
\hline Holothurians & - & - & - & - & - & 5.4 & - & - & 9.2 \\
\hline Phoronidians & 16.1 & - & - & - & - & - & - & - & - \\
\hline Fishes (Gobiidae) & 0.5 & 4.8 & 0.4 & 0.1 & - & 0.2 & 0.5 & - & 0.1 \\
\hline Others & 8.1 & 3.2 & 0.5 & 6.1 & 0.8 & 0.5 & 2.8 & 0.8 & 5.2 \\
\hline
\end{tabular}

At 70-100 $\mathrm{m}$ depth, polychaetes had a significantly lower mean $\delta^{13} \mathrm{C}$ than other organisms. However, only subsurface deposit-feeding polychaetes had isotopic signatures indicating a major terrestrial POM uptake (Table 3 ). High $\delta^{13} \mathrm{C}$ values were observed for all other benthic invertebrates, suggesting a principal reliance on marine organic matter sources. However, surface deposit-feeding polychaetes had isotopic signatures indicating a partial exploitation of terrestrial POM. Flatfishes at 70-100 m were all at the top of the phytoplankton-based food web (Fig. 4), but had different isotopic signatures and diets. Although $\delta^{15} \mathrm{~N}$ was significantly lower in Arnoglossus laterna, suggesting different trophic levels for flatfish at this depth, the significantly lower $\delta^{13} \mathrm{C}$ observed for Solea solea indicated interspecific differences in food source (Table 3). In fact, $S$. solea ate mainly deposit-feeding polychaetes while A. laterna and Buglossidium luteum preyed principally upon crustaceans (Table 4$)$.

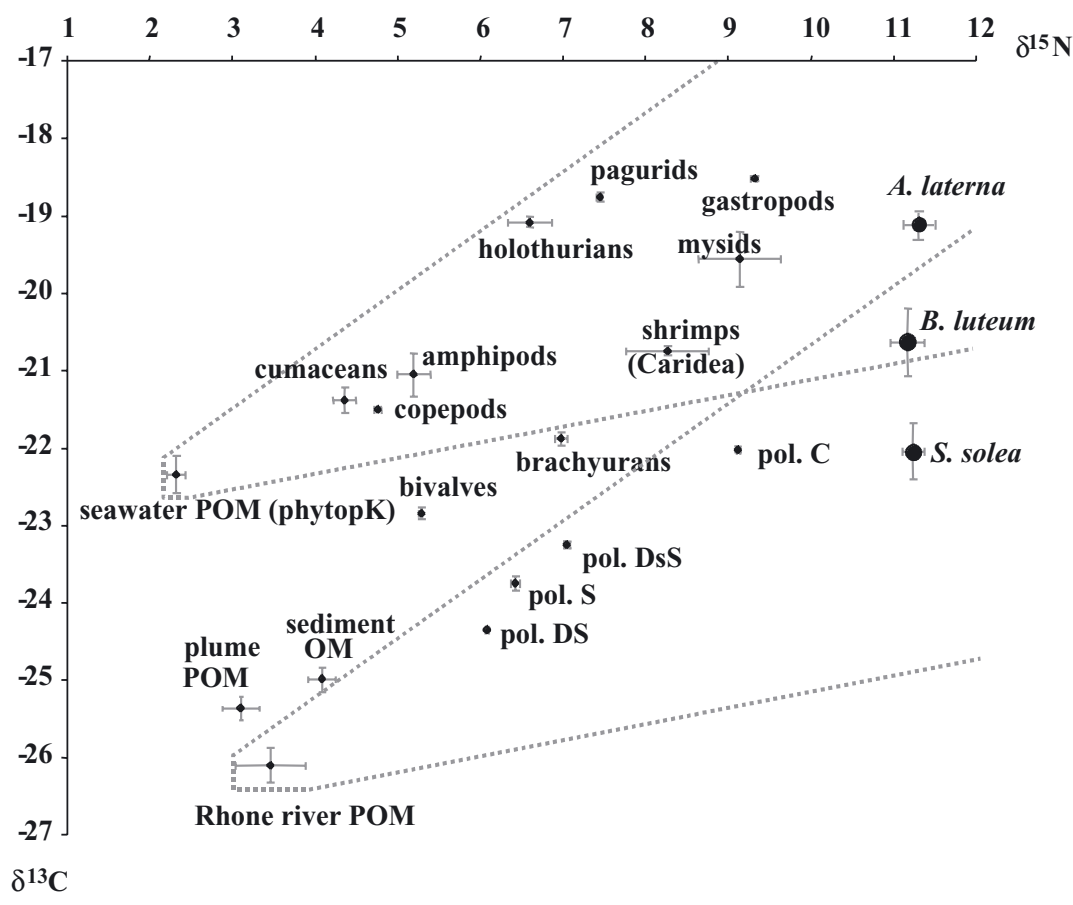

Fig. 3. Plot of $\delta^{13} \mathrm{C}$ versus $\delta^{15} \mathrm{~N}$ (mean $\% \pm$ SE) for main organic matter sources and reservoirs and macrobenthic taxa sampled off the mouth of the Rhone River at 30-50 m depth. Further details as in Fig. 2 


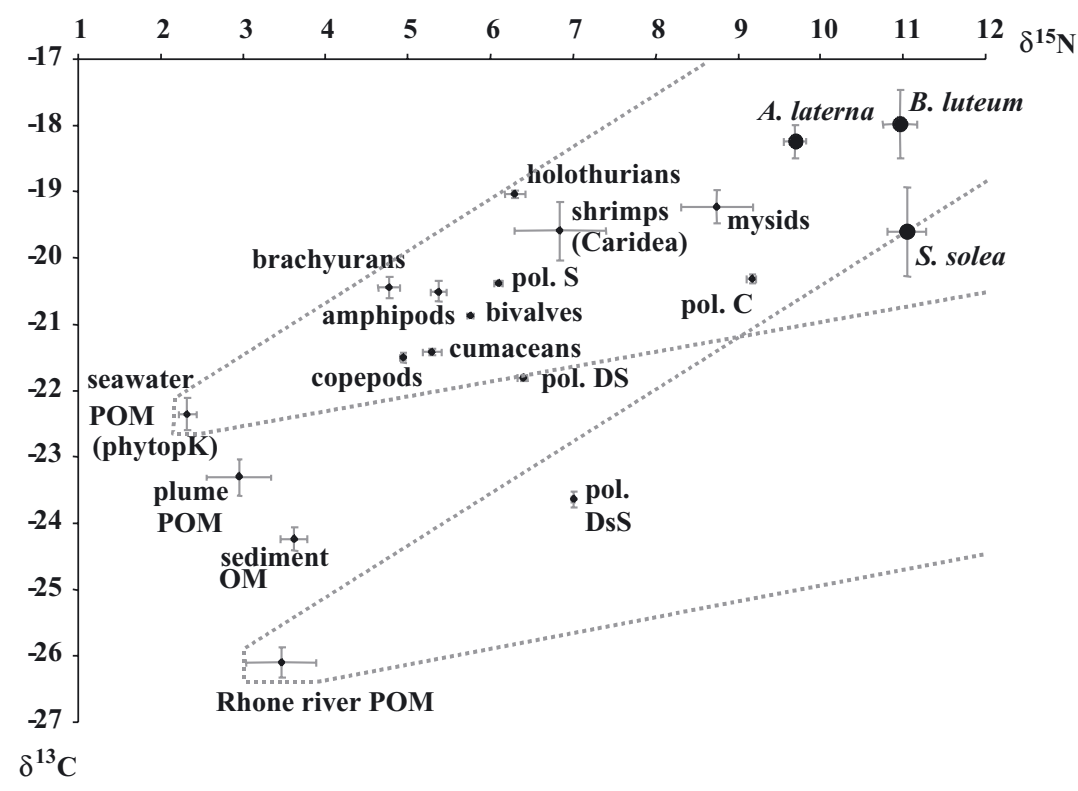

Fig. 4. Plot of $\delta^{13} \mathrm{C}$ versus $\delta^{15} \mathrm{~N}$ (mean \%o $\pm \mathrm{SE}$ ) for main organic matter sources and reservoirs and macrobenthic taxa sampled off the mouth of Rhone River at 70-100 m depth. Further details as in Fig. 2

\section{DISCUSSION}

\section{Origin of organic matter}

The mean $\delta^{13} \mathrm{C}$ values found for terrestrial $(-26.11 \%)$ and marine $(-22.36 \%)$ POM seawards of the Rhone River in the current study were, respectively, within the range of the most common observed carbon signatures of river POM (Riera \& Richard 1996, Lee 2000, Riera et al. 2000) and marine phytoplankton (Herman et al. 2000, Takai et al. 2002). They were sufficiently different $\left(\Delta \delta^{13} \mathrm{C}>3.5 \%\right.$ o $)$ to effectively trace terrestrial and marine organic matter transfer through the benthic ecosystem. Plume water POM and sediment isotopic signatures ranged between those of river and offshore POM irrespective of depth, which was consistent with the input of only 2 principal sources of carbon (river POM and marine phytoplankton) to the Rhone pro-delta benthic ecosystem (Darnaude et al. 2004). Except at $70-100 \mathrm{~m}$, they did not differ significantly, which suggested that most of the pro-delta surface sediment comes from the particulate matter in the overlying water column. Plume water composition can change within a few hours under the combined influence of river discharge and marine currents (Younes 2000). Plume water POM isotopic signatures therefore provide only snapshots of POM composition within the river pro-delta. In contrast, surface sediment signatures reflect POM compositions at a monthly or annual scale, depending on sedimentation rate. This could partially explain the lower $\delta^{13} \mathrm{C}$ values of the surface sediments at $0-20$ and $70-100 \mathrm{~m}$, as most solid inputs from the Rhone River are flushed out to sea during flooding events (Cauwet 1996).

However, our use of $\delta^{13} \mathrm{C}$-based mixing equations revealed important differences in plume POM and sediment organic matter composition with depth. Terrestrial influence was shown to be maximal at $30-50 \mathrm{~m}$ and minimal at $70-100 \mathrm{~m}$, consistent with existing data on the Rhone River plume extension (Demarcq 1985) and river-input sedimentation (Bouloubassi et al. 1997). The Rhone River plume routinely extends above the upper river pro-delta (10 to $60 \mathrm{~m}$ depth) before being diverted westwards by the Liguro-Provencal current. However, during high flooding events, it can cover the whole study zone and spread over depths of 70-100 m (Denis et al. 2001). Consequently, most of the Rhone River POM is deposited within the river pro-delta above the $70 \mathrm{~m}$ isobath, and terrestrial contribution to surface sediment approaches 55 to $80 \%$ at $50 \mathrm{~m}$ depth compared to 30 to $65 \%$ at $90 \mathrm{~m}$ depth (Bouloubassi et al. 1997).

\section{Benthic food webs}

Benthic organisms with similar assumed trophic positions exhibited a wide range of isotopic signatures, even within each depth range. This can be explained partially by interspecific differences in isotopic fractionation during assimilation. Trophic increases in $\delta^{13} \mathrm{C}$ and $\delta^{15} \mathrm{~N}$ are variable among consumers, especially primary consumers (Vander Zanden \& Rasmussen 2001). Trophic increases are more constant in carnivores, but omnivory may substantially increase variability in isotopic signatures (Ansell et al. 1999, Riera et al. 1999).

The isotopic signatures obtained for pagurids, shrimps (Caridea) and brachyurans show that these taxa, which are often presumed to be carnivorous (Mascaro \& Seed 2000, Oh et al. 2001), can directly assimilate substantial quantities of microalgal or terrestrial POM-derived carbon, depending on depth and POM composition. Off the mouth of the Rhone River, phytobenthic production is low, and contributes little to the total primary production (Bodoy \& Plante-Cuny 1980). However, microphytobenthic production peaks at shallow depths (Bodoy \& Plante-Cuny 1980). Benthic diatoms, with high $\delta^{13} \mathrm{C}(>-18 \%$ ) (Riera et al. 1999, Moens et al. 2002), can thus be preferentially ingested by some benthic consumers at $0-20 \mathrm{~m}$, and substantially contribute to their 
diet. This phenomenon, already suggested for Pagurus bernhardus and Crangon crangon (Ansell et al. 1999), would explain the high $\delta^{13} \mathrm{C}$ and low $\delta^{15} \mathrm{~N}$ obtained for pagurids and shrimps (Caridea) at $0-20 \mathrm{~m}$.

\section{Terrestrial POM availability and use}

Amongst invertebrates, the carbon isotopic signature differs according to local POM composition (Hsieh et al. 2000, Lee 2000). Several molluscs from estuarine areas have been shown to react to changes in the suspended POM isotopic signature and directly exploit the terrestrial POM supplied by rivers (Incze et al. 1982, Riera \& Richard 1996, 1997, Hsieh et al. 2000). Variations in POM origin are also reflected in the flesh composition of several estuarine crustaceans, which either directly or indirectly use terrestrial organic matter (Haines \& Montague 1979, Paterson \& Whitfield 1997, Lee 2000, Riera et al. 2000, Chong et al. 2001). Our results show that the isotopic signatures of benthic organisms can vary according to depth and are directly linked to the relative importance of terrestrial material in the total POM pool. Off the mouth of the Rhone River, the highest uptake of terrestrial POM by the benthos was at 30-50 m depth, where most of the total available POM was of terrestrial origin. However, only a small portion of the benthic organisms studied efficiently exploited the terrestrial organic matter supplied by the river.

Marine primary consumers are generally considered as 'opportunistic omnivores', feeding on an undifferentiated mixture of microrganisms, detritus and small meiobenthic species (Haines \& Montague 1979, Kuipers et al. 1981). However, the clearly marine $\delta^{13} \mathrm{C}$ values we observed for cumaceans, copepods and amphipods confirmed active food selection, which was previously suspected but unproven in these crustaceans (Buffan-Dubau et al. 1996, Dittel et al. 2000). The bivalve isotopic signatures reflected a major assimilation of marine POM irrespective of depth. This observation was consistent with the well-documented bivalve exploitation of marine microalgae in preference to other seston particles (Riera \& Richard 1996, Sauriau \& Kang 2000, Raikow \& Hamilton 2001). Bivalves did however, have lower $\delta^{13} \mathrm{C}$ at $30-50 \mathrm{~m}$ depth, demonstrating their ability to partially rely on terrestrial POM when it is dominant in their environment. Among polychaetes, primary consumers showed different $\delta^{13} \mathrm{C}$ variations according to depth, indicating varying reactions to terrestrial POM input. Depending on depth range and water composition, suspensionfeeders ranked either as primary consumers of the terrestrial POM-based food web, or as primary/secondary consumers of the phytoplankton-based food web. This observation is consistent with their usual diet of a variable mixture of phytoplankton, zooplankton and detritic matter (Fauchald \& Jumars 1979). Depositfeeders had lower and more stable $\delta^{13} \mathrm{C}$ values, confirming their ability to significantly exploit terrestrialderived material (Kichuki \& Wada 1996). However, the $\delta^{13} \mathrm{C}$ of surface deposit-feeders reflected the composition of freshly deposited POM (dominated either by marine or terrestrial POM according to depth), whereas the $\delta^{13} \mathrm{C}$ of subsurface deposit-feeders always remained close to that of the sediment. These results stress the importance of feeding behaviour with regard to polychaete sensitivity to terrestrial POM inputs.

Previous isotopic studies of terrestrial POM use by marine or estuarine benthos have rarely included top benthic predators such as fishes (Kwak \& Zedler 1997, Paterson \& Whitfield 1997). Few of these studies have suggested an important impact of terrestrial material (Lee 2000, Sheaves \& Molony 2000). Our results demonstrate that terrestrial POM-derived material was incorporated in the flesh of all the flatfishes studied, but that transfer intensity was dependent on species and depth. Differences in diet usually explain most isotopic signature variation in fishes, either between species (Lee 2000, Sheaves \& Molony 2000) or between habitats within species (Camusso et al. 1998, 1999). However, the feeding behaviour of their prey can also influence fish isotopic signatures. Flatfish $\delta^{13} \mathrm{C}$ in the current study decreased with increasing consumption of deposit-feeding polychaetes, but was minimal for all species only at $30-50 \mathrm{~m}$, where terrestrial POM exploitation by all benthic prey peaked. Thus, the observed terrestrial POM transfers to the adults of Arnoglossus laterna, Buglossidium luteum and Solea solea were a result not only of fish food-preferences but also of the trophic adaptability of their benthic prey.

\section{CONCLUSIONS}

The impact of rivers on coastal ecosystems may be mediated not only as a consequence of their nutrient loads, but also through terrestrial POM inputs into the benthos. Our study demonstrates that terrestrial POM utilisation by marine benthic organisms depends largely on consumer feeding behaviour and POM availability. We found that, unlike estuarine systems, terrestrial influence in deltaic areas may be greatest at intermediate depths $(30-50 \mathrm{~m})$ and not nearshore. These findings extend the general knowledge of how terrestrial organic matter enters the marine environment to be actively taken up into marine benthic food webs, and further stress the significant role of river POM input to the production of commercially important fisheries such as the common sole. 
Acknowledgements. This study was partly supported by the French National Programme on Coastal Ecology (PNEC). Thanks are particularly due to the crews of the OVs 'Antedon' and 'Pr Georges Petit' and to R. Graille for their help in sampling, to G. Taylor for her valuable assistance with stable isotope analysis, and to anonymous reviewers for their valuable comments on the manuscript.

\section{LITERATURE CITED}

Ansell AD, Comely CA, Robb L (1999) Distribution, movements and diet of macrocrustaceans on a Scottish sandy beach with particular reference to predation on juvenile fishes. Mar Ecol Prog Ser 176:115-130

Ardisson PL, Bourget E (1997) A study of the relationship between freshwater runoff and benthos abundance: a scale oriented approach. Estuar Coast Shelf Sci 45: 535-545

Bodoy A, Plante-Cuny MR (1980) Evaluation simultanée des biomasses et productions primaires phytoplanctonique et microphytobenthique en milieu côtier. C R Hebd Séances Acad Sci Sér D 290:667-670

Bouilllon S, Chandra Mohan P, Sreenivas N, Dehairs F (2000) Sources of suspended organic matter and selective feeding by zooplankton in an estuarine mangrove ecosystem as traced by stable isotopes. Mar Ecol Prog Ser 208:79-92

Bouloubassi I, Lipiatou E, Saliot A, Tolosa I, Bayona JM, Albaiges J (1997) Carbon sources and cycle in the western Mediterranean - the use of molecular markers to determine the origin of organic matter. Deep-Sea Res II 44: 781-799

Buffan-Dubau E, De Wit R, Castel J (1996) Feeding selectivity of the harpacticoid copepod Canuella perplexa in benthic muddy environments demonstrated by HPLC analyses of chlorin and carotenoid pigments. Mar Ecol Prog Ser 137: 71-82

Camusso M, Martinotti W, Balestrini R, Guzzy L (1998) C and $\mathrm{N}$ stable isotopes and trace metals in selected organisms from the river Po delta. Chemosphere 37:2911-2920

Camusso M, Balestrini R, Martinotti W, Arpini M (1999) Spatial variations in trace metal and stable isotope content of autochtonous organisms and sediments in the river Po. Aquat Ecosyst Health Manag 2:93-53

Cauwet G (1995) Apports du Rhône en carbone et azote dissous et particulaire de juin 1994 à juin 1995. In: Colloque Potam'mes. 7es Rencontres de l'Agence Régionale pour l'Environnement Provence-Alpes-Côte d'Azur, Digne-lesBains, p 263-271

Cauwet G, Gadel F, De Souza Sierra, MM, Donard O, Ewald M (1990) Contribution of the Rhône River to organic carbon inputs to the northwestern Mediterranean Sea. Cont Shelf Res 10:1025-1037

Chanton J, Lewis G (2003) Examination of coupling between primary and secondary production in a river-dominated estuary: Apalachicola Bay, Florida, USA. Limnol Oceanogr 47:683-697

Chong VC, Low CB, Ichikawa T (2001) Contribution of mangrove detritus to juvenile prawn nutrition: a dual stable isotope study in a Malaysian mangrove forest. Mar Biol 138:77-86

Cloern JE (2001) Our evolving conceptual model of the coastal eutrophication problem. Mar Ecol Prog Ser 210: 223-253

Darnaude AM, Harmelin-Vivien ML, Salen-Picard C (2001) Food partitioning among flatfish (Pisces: Pleuronectiforms) juveniles in a Mediterranean coastal shallow sandy area. J Mar Biol Assoc UK 81:119-127

Darnaude AM, Salen-Picard C, Polunin NVC, HarmelinVivien ML (2004) Trophodynamic linkage between river run-off and coastal fishery yield elucidated by stable isotope data in the Gulf of Lions (NW Mediterranean). Oecologia 138:325-332

Demarcq H (1985) Applications de la télédétection infrarouge et visible en océanographie: étude de la zone rhodanienne, observations des zones de production dans le Golfe du Lion et estimation de l'éclairement solaire global en Méditerranée occidentale. PhD thesis, University of Aix-Marseille II, Marseilles

De Niro MJ, Epstein S (1978) Influence of diet on the distribution of carbon isotopes in animals. Geochim Cosmochim Acta 42:495-506

Denis L, Grenz C, Alliot E, Rodier M (2001) Temporal variability in dissolved inorganic nitrogen fluxes at the sediment-water interface and related annual budget on a continental shelf (NW Mediterranean). Oceanol Acta 24: 85-97

Dittel AI, Epifanio CE, Schwalm SM, Fantle MS, Fogel ML (2000) Carbon and nitrogen sources for juvenile blue crabs Callinectes sapidus in coastal wetlands. Mar Ecol Prog Ser 194:103-112

Dufour E, Gerdeaux D (2001) Apport des isotopes stables $\left({ }^{13} \mathrm{C} /{ }^{12} \mathrm{C},{ }^{15} \mathrm{~N} /{ }^{14} \mathrm{~N},{ }^{18} \mathrm{O} /{ }^{16} \mathrm{O},{ }^{36} \mathrm{~S} /{ }^{34} \mathrm{~S},{ }^{87} \mathrm{Sr} /{ }^{86} \mathrm{Sr}\right)$ aux études écologiques sur les poissons. Cybium 25:369-382

Fauchald K, Jumars PA (1979) The diet of worms: a study of polychaete feeding guilds. Oceanogr Mar Biol Annu Rev 17:193-284

Haines EB, Montague CL (1979) Food sources of estuarine invertebrates analysed using ${ }^{13} \mathrm{C} /{ }^{12} \mathrm{C}$ ratios. Ecology 60 : $48-56$

Herman PJM, Middelburg JJ, Widdows J, Lucas CH, Heip CHR (2000) Stable isotopes as trophic tracers: combining field sampling and manipulative labelling of food resources for macrobenthos. Mar Ecol Prog Ser 204:79-92

Hsieh HL, Kao WY, Chen CP, Liu PJ (2000) Detrital flows through the feeding pathway of the oyster (Crassostrea gigas) in a tropical lagoon: $\delta^{13} \mathrm{C}$ signals. Mar Biol 136: $677-684$

Incze LS, Mayer LM, Evelyn BS, Macko SA (1982) Carbon inputs to bivalve molluscs: a comparison of two estuaries. Can J Fish Aquat Sci 39:1348-1352

Josefson AB, Conley DJ (1997) Benthic response to a pelagic front. Mar Ecol Prog Ser 147:49-62

Kaehler S, Pakhamov EA, McQuaid CD (2000) Trophic structure of the marine food web at the Prince Edward Islands (Southern Ocean) determined by $\delta^{13} \mathrm{C}$ and $\delta^{15} \mathrm{~N}$ analysis. Mar Ecol Prog Ser 208:13-20

Kichuki E, Wada E (1996) Carbon and nitrogen stable isotope ratios of deposit-feeding polychaetes from the Nanakita River estuary, Japan. Hydrobiologia 321:69-75

Kuipers BR, De Wilde PAWJ, Creutzberg F (1981) Energy flow in a tidal flat ecosystem. Mar Ecol Prog Ser 5:215-221

Kwak TJ, Zedler JB (1997) Food web analysis of southern California coastal wetlands using multiple stable isotopes. Oecologia 110:262-277

Lee SY (2000) Carbon dynamics of Deep Bay, eastern Pearl River estuary, China. II. Trophic relationship based on carbon and nitrogen stable isotopes. Mar Ecol Prog Ser 205: $1-10$

Lochet F, Leveau M (1990) Transfers between a eutrophic ecosystem, the river Rhône, and an oligotrophic ecosystem, the north-western Mediterranean Sea. Hydrobiologia 207:95-103

Mascaro M, Seed R (2000) Foraging behavior of Carcinus 
maenas (L.): comparisons of size-selective predation on four species of bivalve prey. J Shellfish Res 19:283-291

Maslowski J (2003) Effects of trophic conditions on benthic macrofauna in the vicinity of the River Swina mouth (Pomerian Bay; southern Baltic Sea). Oceanologia 45: 41-52

Minagawa M, Wada E (1984) Stepwise enrichment of ${ }^{15} \mathrm{~N}$ along food chains: further evidence and the relation between $\delta^{15} \mathrm{~N}$ and animal age. Geochim Cosmochim Acta 48:1135-1140

Moens T, Luyten C, Middelburg JJ, Herman PJM, Vincx M (2002) Tracing organic matter sources of estuarine tidal flat nematodes with stable carbon isotopes. Mar Ecol Prog Ser 234:127-137

Oh CW, Hartnoll RG, Nash RDM (2001) Feeding ecology of the common shrimp Crangon crangon in Port Erin Bay, Isle of Man, Irish Sea. Mar Ecol Prog Ser 214:211-223

Ostrom PH, Fry B (1993) Sources and cycling of organic matter within modern and prehistoric food webs. In: Engel $\mathrm{MH}$, Macko SA (eds) Organic geochemistry. Plenum Press, New York, p 785-798

Paterson AW, Whitfield AK (1997) A stable carbon isotope study of the food-web in a freshwater-deprived South African estuary, with particular emphasis on the ichthyofauna. Estuar Coast Shelf Sci 45:705-715

Peterson BJ, Howarth RW, Garritt RH (1985) Multiple stable isotopes used to trace the flow of organic matter in estuarine food webs. Science 227:1361-1363

Pinnegar JK, Polunin NVC (1999) Differential fractionation of $\delta^{13} \mathrm{C}$ and $\delta^{15} \mathrm{~N}$ among fish tissues: implications for the study of trophic interactions. Funct Ecol 13:225-231

Pinnegar JK, Polunin NVC (2000) Contributions of stableisotope data to elucidating food webs of Mediterranean rocky littoral fishes. Oecologia 122:399-409

Polunin NVC, Morales-Nin B, Pawsey WE, Cartes JE, Pinnegar JK, Moranta J (2001) Feeding relationships in Mediterranean bathyal assemblages elucidated by stable nitrogen and carbon isotope data. Mar Ecol Prog Ser 220: $13-23$

Pont D (1997) Les débits solides du Rhône à proximité de son embouchure: données récentes (1994-1995). Rev Géogr Lyon 72:23-33

Post DM (2002) Using stable isotopes to estimate trophic position: models, methods, and assumptions. Ecology 83: 703-718

Preston T, Owens NJP (1983) Interfacing an automatic elemental analyser with an isotope ratio mass spectrometer: the potential for fully automated total nitrogen and nitrogen-15 analysis. Analyst 108:971-977

Raikow DF, Hamilton SK (2001) Bivalve diets in a midwestern US stream: a stable isotope enrichment study. Limnol Oceanogr 46:514-522

Renones O, Polunin NVC, Goni R (2002) Size related dietary

Editorial responsibility: Otto Kinne (Editor),

Oldendorf/Luhe, Germany shifts of Epinephelus marginatus in a western Mediterranean littoral ecosystem: an isotope and stomach content analysis. J Fish Biol 61:122-137

Riera P, Richard P (1996) Isotopic determination of food sources of Crassostrea gigas along a trophic gradient in the estuarine bay of Marennes-Oléron. Estuar Coast Shelf Sci 42:347-360

Riera P, Richard P (1997) Temporal variation of $\delta^{13} \mathrm{C}$ in particulate organic matter and oyster Crassostrea gigas in Marennes-Oléron Bay (France): effect of freshwater inflow. Mar Ecol Prog Ser 147:105-115

Riera P, Stal LJ, Nieuwenhuize J, Richard P, Blanchard G, Gentil F (1999) Determination of food sources for benthic invertebrates in a salt marsh (Aiguillon Bay, France) by carbon and nitrogen stable isotopes: importance of locally produced sources. Mar Ecol Prog Ser 187:301-307

Riera P, Montagna PA, Kalke RD, Richard P (2000) Utilisation of estuarine organic matter during growth and migration by juvenile brown shrimp Penaeus aztecus in a South Texas estuary. Mar Ecol Prog Ser 199:205-216

Salen-Picard C, Arlhac D (2002) Long-term changes in a Mediterranean benthic community: relationships between the polychaete assemblages and hydrological variations of the Rhône river. Estuaries 25:1121-1130

Sauriau PG, Kang CK (2000) Stable isotope evidence of benthic microalgae-based growth and secondary production in the suspension feeder Cerastoderma edule (Mollusca, Bivalvia) in the Marennes-Oléron Bay. Hydrobiologia 440:317-329

Sempéré R, Charrière B, Van Wambeke F, Cauwet G (2000) Carbon inputs of the Rhône River to the Mediterranean Sea: biogeochemical implications. Global Biogeochem Cycles 14:669-681

Sheaves M, Molony B (2000) Short-circuit in the mangrove food chain. Mar Ecol Prog Ser 199:97-109

Takai N, Mishima Y, Yorozu A, Hoshika A (2002) Carbon sources for demersal fish in the western Seto Inland Sea, Japan, examined by $\delta^{13} \mathrm{C}$ and $\delta^{15} \mathrm{~N}$ analyses. Limnol Oceanogr 47:730-741

Touzani A, Giresse P (2002) The Rhone River pro-delta: shortterm $\left(10^{0}-10^{3} \mathrm{yr}\right)$ sedimentation patterns and human impact. J Coast Res 18:102-117

Vander Zanden MJ, Rasmussen JB (2001) Variation in $\delta^{15} \mathrm{~N}$ and $\delta^{13} \mathrm{C}$ trophic fractionation: implications for aquatic food web studies. Limnol Oceanogr 46:2061-2066

Wada E, Mizutani H, Minagawa M (1991) The use of stable isotopes for food web analysis. Crit Rev Food Sci Nutr 30 361-371

Younes WAN (2000) Observation à haute définition spatiale de la variabilité temporelle à différentes échelles d'un hydrosystème estuarien, le Rhône, et de son influence sur les eaux côtières. PhD thesis, University of Aix-Marseille II, Marseilles

Submitted: November 17, 2003; Accepted: March 18, 2004 Proofs received from author(s): June 21, 2004 